\title{
INVESTIGATIONS ON BACTERIA CAUSING SUBCLINIAL MASTITIS IN CATTLE
}

\author{
F. A. El-Shaboury And Ola. A. Basha. \\ Animal Health Research Institute, Alexandria branch. Bacteriology Dept
}

\begin{abstract}
This research was carried on 80 quarter out of 600 quarter milk samples collected aseptically from 150 apparently healthy cows in 4 private farms at Alexandria Governorate (Abees - Ameria- Borg-ElArab and Mariout) and prove the affection of subclinical mastitis by use California mastitis test. The total incidence of subclinical mastitis in Alexandria Governorate was $13.33 \%$. While the incidence in 4 farms (Abees - Ameria-Borg-El-Arab and Mariout) were ( $14.3 \%$, $13.9 \%, 12.5 \%$, and $10 \%$ ) respectively. The number of the bacterial isolates in these investigation was 92 isolates, while the number and frequency percentages of the isolates were Staphylococcus aureus 23 (25\%), Streptococcus agalactia 20 (21.37\%), Streptococcus dysagalactia 8 isolates (8.69\%), E-coli 8 (8.69\%), Arctenobacterium bovis 18 (19.26\%), Pseudomonas aeruginosa 13 (14.13\%), and Pseudomonas fluorescens 2 isolates (2.17\%). Also, the sensitivity of the isolated organisms to antibiotics were discussed. It was found that most of the isolated species were highly sensitive to Chloramphenicol, Gentamycin and Cephaloxin and less sensitive to Tetracyclin and Streptomycin but were resistance to Penicillin and Amoxicillin. Public health significance was discussed.
\end{abstract}




\section{INTRODUCTION}

The most important disease affecting udder is mastitis which is a problem of considerable economic importance in dairy industry through out the world. So the most mastitic cases occure in subclinical forms, hence the diseased animal continues, for a time to be a dangerous source of infection (Keisler,1981). The subclinical mastitic milk may have a public health importance, since it may be due to a human pathogen which will cause an infection to the consumers of raw or inadequately heated milk (Wilesmith et al.,1986 and Sedeek et al.,2000). The subclinical mastitis constitutes a herd problem and the loss is nearly three times that of the clinical form. More attention had been focused for the diagnosis of subclinical mastitis (Joshi et al ., 1976). Ghazi and Nair (2006) mentioned that the subclinical mastitis always characterized by the presence of germs, only, there is a hyperleucocytosis and certain modifications of the chemical properties of milk. This disease is considered as multifactorial where development of infection depends on presence of mastitic pathogens and a series of additional factors that act concomitantly (Eman et al., 2006). The most predisposing factors causing a lower resistance of udder for bacterial invasion are the general healthy condition of animal, the milking machine and bad milking habits (Tawfik et al.,1984). The subclinical mastitis problem was studied by several authors in different countries, Narendra et al.,(1982) in India, Hussein et al ., (1984) in Pakestan, Aleksandrova (1986) in Bulgaria, Lopes et al., (1990) in Brazil and Controbi et al., (1992) in Argentina. In Egypt this problem was studied by different authors, (Aziz et al.,1975, Abdelkarim and El-ashmawy, 1979, Bakr, 1986, El-Bayomi and Mahmoud, 1987, Aki, 1988, Amal et al ., 1990, Nawal et al., 1996, Seddek et al., 1999, Awad and Abeer,2003).and Hamdy et al .,(2007).

The present work was aimed to investigate the presence of the disease in 
some farms in different localities at Alexandria Governorate, together with the identification of the bacterial causative agent. Moreover, due to the public health hazard of antibiotic resistance for microbial antibiotic sensitivity patterns for infections were evaluated.

\section{MATERIAL AND METHODS}

\section{Collection of samples:}

Milk samples were collected from farms in 4 different areas in Alexandria Governorat from dairy apparently healthy udder of cows. The udder was thoroughly washed with soap and water, then dried and swabbed with $70 \%$ alcohol. The first stream of milk was discarded, then about $10-15 \mathrm{ml}$ of milk was collected from the 4 quarters of the udder into a sterile tube. All samples were subjected to California mastitis test (C.M.T) according to Schalm et al.(1971). Samples giving $(++)$ and over were considered positive and were marked and transported immediately to the laboratory where they were kept in refrigerator until bacteriological examination.

\section{Bacteriological examination:}

The milk samples were centrifuged at $300 \mathrm{rpm}$ for 15 minutes and a loopful from the sedment of the pre-incubated milk sample at $37 \mathrm{c}^{\circ}$ over night, was streaked on nutrient agar, blood agar and MacConkeys agar plates. The inoculated plates were incubated at $37 \mathrm{c}^{\circ}$ for 48 hours and examined for bacterial growth. Isolated colonies were picked up and subcultured on the appropriate media for purification, studying the cultural characteristics, and identification by microscopic examination and biochemical reactions according to Cruickshank et al .(1975) and Koneman et al.(1988).

\section{En-vetro antibiotic sensitivity test:}

The disc and the agar diffusion method described by Cruickshank et al .(1975) was performed. Aportion of a single bacterial colony was selected and inoculated into $4 \mathrm{ml}$ trypticase broth and incubated at $37 \mathrm{c}^{\circ}$ $\overline{\bar{K} \text { Kafrelsheikh Vet. Med. J. Vol. } 5 \text { No. } 2 \text { (2007) }}$ 
for 18 hours. The culture was flooded on to the surface of well dried Muller - Hinton agar plates. The plates were tipped and excess of fluid was removed with a pipette, after being sure that entire surface was covered with the inoculum. The bacteria were allowed to settle for 15 minutes at $37 \mathrm{c}^{\circ}$. The antibiotic discs were aseptically overlaid. The plates were allowed to stand for 30 minutes at room temperature after application of the discs, then after over night incubation at $37 \mathrm{c}^{\circ}$, the plates were examined for inhibition zones. The interpretation of results were carried out according to Finegold and Martine (1992).

\section{RESULTS}

\section{Detection of subclinical mastitis:}

As shown in Table (1) and (2) the results of examination of milk samples collected from 600 quarters of 150 apparently healthy cows for mastitis using California mastitis test revealed that 80 milk samples $(13.33 \%)$ were positive for California mastitis test and were considered as subclinical mastitic cases while 520 milk samples (86.66) were normal cases.

\section{Bacteriological findings:}

As shown in Table (3) 80 subclinical mastitic milk samples were examined bacteriologically, all of them were positive for bacterial growth in an incidence of $100 \% .7$ different types of microorganisms were isolated and identificated as Staphylococcus aureus 23 isolates (25\%), Streptococcus agalactia 20 isolates (21.73\%), Streptococcus dysagalactia 8 isolates (8.69\%), E-coli 8 isolates (8.69\%), Arctenobacterium bovis 18 isolates $(19.26 \%)$, Pseudomonas aeruginosa 13 isolates (14.13\%) and Pseudomonas fluorescens 2 isolates (2.17\%). The distribution of the isolated bacteria causing subclinical mastitis in different 4 localities examined in Alexandria Governorate were illustrated in Table (2). 


\section{In - vetro sensitivity test:}

As shown in Table(4) 70 isolates of 7 different types of bacteria species isolated from the milk of subclinical mastitic cows were tested for their sensitivity to 9 different antimicrobial agents. The most effective antibiotics were Chloramphinicol, Gentamycin and Cephaloxin and followed by Tetracyclin and Stryptomycin which were less effective but they showed high resistance to Pencillin and Amoxicillin.

Table (1): Incidence of subclinical mastitis.

\begin{tabular}{|c|c|c|c|c|c|}
\hline \multirow{3}{*}{$\begin{array}{c}\text { Total No. of } \\
\text { examined } \\
\text { animals }\end{array}$} & \multirow{3}{*}{$\begin{array}{l}\text { Total No. of } \\
\text { examined } \\
\text { quarter milk } \\
\text { samples }\end{array}$} & \multicolumn{4}{|c|}{ Apparently healthy quarter samples } \\
\hline & & \multicolumn{2}{|c|}{ Subclinical cases } & \multicolumn{2}{|c|}{ Normal cases } \\
\hline & & No. & $\%$ & No. & $\%$ \\
\hline 150 & 600 & 80 & 13.33 & 520 & 86.66 \\
\hline
\end{tabular}

Table (2): Incidence of subclinical mastitic cows in The examined farms.

\begin{tabular}{|c||c||c||c||}
\hline \multicolumn{1}{|c||}{ Farm } & $\begin{array}{c}\text { Number of } \\
\text { examined quarter }\end{array}$ & $\begin{array}{c}\text { Positive cases } \\
\text { of examined } \\
\text { quarter milk } \\
\text { samples by } \\
\text { C.M.T. }\end{array}$ & Percentages \\
\hline \hline Abees & 260 & 37 & 14.3 \\
El-Amreia & 180 & 25 & 12.5 \\
Borg El-Arab & 80 & 10 & 10.0 \\
\hline Mariout & 80 & 8 & $\mathbf{1 3 . 3 3}$ \\
\hline Total & $\mathbf{6 0 0}$ & $\mathbf{8 0}$ & \\
\hline
\end{tabular}

$\mathrm{C} \mathrm{M} \mathrm{T} \mathrm{=} \mathrm{Califonia} \mathrm{mastitis} \mathrm{test.}$

$\overline{\text { Kafrelsheikh Vet. Med. J. Vol. } 5 \text { No. } 2 \text { (2007) }}$ 


\section{DISCUSSION}

Several methods have been reported for the detection of mastitis, The isolation of the causative micro-organisms is the most accurate, yet it is expensive and time consuming. Therefor the need for a simple, quite,sensitive, rapid and reliable test sufficient to be applied on a large scale of animals is highly required. California mastitis test was recommended as a preliminary screening test for detection of subclinical mastitis (Dedie and Kieliverin 1960). This test indicator is one of the most reliable tests in diagnosis of subclinical mastitis in diary herds. However, the test is used to diagnose subclinical mastitis in the field, but to clarify the causative organism and for better treatment based on the sensitivity test bacteriological diagnosis is required. From the obtained data the incidence percentages of subclinical mastitis in 4 farms of different localities in Alexandria Governorate (Abees -El- AmeriaBorg-El-Arab and Mariout) were 14.3\%,13.9\%, 12.5\%,and $10 \%$ respectively ( Table 2 ) with a total incidence $(13.33 \%)$. The incidence is much less than that obtained by Chanders and Baxi (1975), Tsnoev et al. (1976), Glazer(1977), Verma (1978), Abdelkarim and El-Ashmawy (1979) and Ibtisam et al .(1993) who found that subclinical mastitis between dairy cows was $43.6 \%, 56 \%, 31.8 \%, 45 \%, 60 \%$ and $56.43 \%$ respectively. This lower incidence of subclinical mastitis in the present work reflects the good hygienic measures of examined, well fed animals and good immune status of them. On the other side the result is nearly similar to that recorded by Brodauf (1965) 18\% and Seddek et al. (1999) $11.38 \%$. On the other hand several authors failed to record any cases of subclinical mastitis in dairy cows, this indicates that the hygienic measures applied were very restricted and well controlled (Heever et al. 1976, Misra,1976, Sharma et al., 1977, Klastrup and Halliwell 1977, 
and Abd El-Halim, 1979). Besides, the difference of incidence percentages may be due to variation in enviromental conditions and food programme followed in these farms specially if the ration is mixed with selenium and vitamine E supply which improve the udder healthy condition (weiss et al., 1990). The results of bacteriological examination of 80 subclinical mastitic milk samples showed that all samples were positive for bacterial growth in an incidence of $100 \%$ (Table 3). This finding nearly coincides with the observation obtained by Verma et al.(1978), Anderson et al. (1982) and Seddek et al.(1999). From the mentioned data in Table(3) it was found that the main causative bacterial agents responsible for subclinical mastitis in dairy cows were Staphylococcus aureus, Streptococcus agalactia, streptococcus dysagalactia, Ecoli ,Arctenobacterium bovis and Pseudomonas aeruginosa as well as 12 cases of mixed infection mostly Staphylococcus aureus, E-coli and Arctenobacterium bovis. Similar causative agents were previously described by Jain (1979) Abd El-All (1989) and Seddek etal.(1999). In this investigation the numbers and frequency of percentages of the isolates were as such Staphylococcus aureus (29.34\%), Streptococcus agalactia (21.73\%), Streptococcus dysagalactia (8.69\%)E-coli (8.69\%), Arctenobacterium bovis (19.26\%), Pseudomonas aeruginosa(14.13\%) and Pseudomonas fluorescens $(2.17 \%)$. In this respect the present results are nearly similar to those obtained by different authors, Amal, et al.(1990), Controbi, et al.(1992) ,Jha, et al.(1994), Aydin, et al.(1995) and Seddek, et al. (2000) who isolated different organisms which included Staphylococcus aureus (28.57\%), E-coli (20.5\%), Streptococcus agalactia(11.76\%), Streptococcus dysagalactia (6.3\%), Arctenobacterium bovis $(9.8 \%)$ and Pseudomonas aeruginosa(15.6\%)respectively.Ahigher incidence was obtained by El-Bayomi and Mahmoud (1987) and Morselt et al.(1995) who reported that Stryptococcus agalactia and Kafrelsheikh Vet. Med. J. Vol. 5 No. 2 (2007) 
Staphylococcus aureus were the predominant organisms with an incidence of (55.29\%) and (65\%) respectively. Also Rottschedt (1994) recorded that the main causative agent of subclinical mastitis in cows were Streptococcus agalactia and Staphylococcus aureus with a higher incidence (94.4\%) and (58.8\%) respectively, while Wilson et al. (1996) stated that the main causative bacterial agents were Staphylococcus coagulase negative, E-coli, Streptococcus agalactia and Streptococcus dysagalactia with an incidence of $21 \%, 40 \%, 63 \%$ and $48 \%$ respectively. It should be mentioned that the high incidence of the isolated bacteria causing subclinical mastitis reported by several authors may be attributed to the heavy contamination of bedding, housing, food materials, water, air and equipments which affect the healthy condition of animals and udder (Zecconi et al. 1994, Roberson et al. 1994 and Leibisch et al. 1994). Mixed infection had been observed in this study mainly Staphylococcus aureus with E-coli denoting the complexity of the disease, this is in agreement with Jain (1979) who stated that the Staphylococcus aureus may predispose the herd to infection by coliforms and other pathogens.

As regards the sensitivity test of the bacterial isolates, the obtained results showed that Chloramphenicol, Gentamycin and Cephaloxin were highly sensitive agents against most of the strains, while Tetracyclin and Stryptomycin were the less effective. On the other hand, most of the strains were resistant to Pencillin and Amoxicillin. The previously mentioned results are supported by several authors (Jha et al.,1994, Aydinet al.,1995 and Nawal et al., 1996).

In conclusion, the subclinical mastitis in dairy cows is one of the most important serious disease due to public health importance, since Streptococci, E-coli and Staphylococci which are pathogenic for human 
being are excreted in milk and would give rise to scarlet fever, septic sore throat, pyogenic infection and food poisoning to those consuming raw milk. Therefore good managment practices such as milker's hygiene, sanitization of milking machine as well as controlling the predisposing factors should be considered among the major prophylactic measures to minimize the occurrence of the disease. Identification of the causative organisms and its sensitivity testing are important measures for the treatment and prevention of the disease.

\section{REFERENCES}

- Abdel-All, B.E.(1989): Studies of bacteria causing mastitis in cattle in Assiut. Ph.D. Microbiology. Thesis, Assiut niversity.

- Abdel Halim, M.M. (1979): Studies on mycotic mastitis. Thesis M. V. Sc. Fac. Vet. Med. Cairo Univ.

- Abdel-Karim, A.M. and El-Ashmawy, A.M. (1979): Diagnosis of subclinical mastitis in Iraqi dairy cattle. Assiut Vet. Med. J. 6. 11/ 12: 283.

- Aki, K.M. (1988): Studies on subclinical mastitis in cattle and buffaloes in Behera Governorate, M.V.Sc.Thesis. Alexandria univ.

- Aleksandrova, S.(1986): Microflora of subclinical mastitis in cows in the Burgas region of Bulgaria. Vet.Sbirka 84: 14-16.

- Amal, A. El-Rashidy;El-Garhy, M.M.; Metias, K.N. ;Ahmed A.N.and Tawfik, M.S.(1990):Incidence of bovine subclinical mastitis in individual cases belonging to Egyptian Farmers in Giza province. Fourth Sci. cong. Fac. Vet.Med. Assiut Univ. 789-796.

- Anderson, K.L. Smith, A.R.;Gustaffon, B.K.;Spaker, S.L. and $\overline{\bar{K} \text { Kafrelsheikh Vet. Med. J. Vol. } 5 \text { No. } 2 \text { (2007) }}$ 
Whitmore, H.L.(1982): Diagnosis and treatment of acute mastitis in large dairy herd. J. Am. Vet. Med. Ass., 181:690693.

- Awad ,W.S.and Abeer, A.A.(2003): Diagnosis of subclinical mastitis in lactating cows using concentration of milk immunoglobul G, and NA Gase activity. J. Egypt Vet. Med. Assoc., 63 No. 6:73-83.

- Aydin, F. Lelogly, N.,Sahin, M.; Colak, A. and Otlu, S. (1995): Identification and antibiotic sensitivity of microorganisms causing clinical and subclinical mastitis in diary cows in the Kars district. Pendik Veteriner Mikrobiyoloji Dergsi . 26(1)55-65.

- Aziz, A.A. Zein El-Abdin, V. and Farrage, Y.A. (1975): Control of subclinical mastitis in buffaloes dairy herd. Egyptian J. Vet. Sci. 12. 135-141.

- Baker, M.E.A. (1986): Comparative studies on different methods used for detection of subclinical mastitis in dairy animals Ph. D. Thssis. Cairo Univ.

- Brodauf, H. (1965): Evaluation of the schalm mastitis test from experiences of the cattle health service in Baden. Arch. Lebens mittethxg, 16;250-253.

- Chanders, S. and Baxi, K. K.(1975): Diagnosis and treatment of subclinical mastitis in cows . Indian Vet. J. 52:273.

- Chruichshank, R. Duguid, J. P.; Mormion, B.R. and Swoin, R. H. A. (1975): Medical microbiology $2^{\text {nd }}$ Vol.12 ed. Living- 
stone, Edinburgh, London and New York.

- Controbi,O. N. P. de;Cuadrado A. M. A. de; Alcaraz, L. E.; Laciar, A.L.and Milan, M.C. de (1992): Prevalence of Staph.aureus isolated from subclinical bovine mastitis in the daries of Sanluis City. Revista Argentina de Microbiologica. 24(2):73-80.

- Dedie, K. and Kielivein, G.(1960): Alkyl aryl compound reagent for detection of bovine mastitis. Rinder tuber.M. Brucellose

9 ,

19-27, 35-43.

- El-Bayomi, K. H. M. and Mahmoud, A.A. (1987): Some gentic and enviromental factors affecting the incidence of subclinical mastitis in dairy cows. Vet. Med.J., 35:269-285.

- Eman, A. Ahmed; El-Sangary, F. S. and Abu-Zead, A. A. (2006): Bacterial and Biochemical studies on mastitis of cattle in Sharkia Governorate. Assiut. Vet. Med. J. Vol.52 No.109:207-214.

- Finegold,S.M. and Martin, W.J.(1982): Diagnostic Microbiology. $6^{\text {th }}$ Ed. The C.V. Mosby Co. St. Louis, Tornto, London.

- Ghazi, K. and Nair, A. (2006):Incidence of mastitis in various bovine breedings in Tiaret area. (Algeria). Assiut. Vet. Med.J.Vol. 52:198-206 .

- Glazer, T. (1977): Clinical and experimental studies on the efficacy of bovine mastitis control programme in the olsztyn region of Poland. Zeszyty Nau Kowe Akademii RelinczoTechnniczing Wolsztynios Veterynario 9,3,93, Cited after Vet. 
Bull. 46,10 (1978).

- Hamdy, H.O; Tarek ,H.A. and Adry, M.B. (2007): Studies on the Frisian Dairy Cattle Infected with clinical Mastitis In Sharkia Governorate. The second Sci. Conf., January 25-28, Banha. Fac. Vet. Med. (Moshtohor), Banha University. Egypt.

- Heever, L. W.; Vanden and Turner, G.V. S. (1976): The comparative incidence of subclinical mastitis .J. S. Afr. Vet. Med. Assoc. 47,4.263.

- Hussian, M.; Neem, K. and Iabel, N.(1984): subclinical mastitis in cows and buffaloes identification and drug susceptibility of causative organisms. Pakistan Vet.J.4,161-164.

- Ibtisam, E. Mohamed Mohamed,G.E. and El-Owni, O.A.O. (1993): Study onte incidence and etiology of bovine mastitis in Sudan. $2^{\text {nd }}$. Sci. Cong. Egyptian Society for cattle Diseases. Assiut Egypt. 326-336.

- Jain, N.C.(1979): Common mammary pathogens and factors in infection and mastitis. J. of dairy science. 62,128-134.

- Jha, V.C.; Thakur, R.P. and Yaday, I.N. (1994): Bacterialspecies isolated from clinical bovine mastitis and their antibiotic sensitivity patterns. Vet. Review (Kathmanda) 9 (1):21-23.

- Joshi, S.V. ; Prasad, J.and Rekib, A. (1976): Studies on the field diagnosis of subclinical mastitis .Indian Vet. J.53,10,752.

- Keisler, E.M. (1981): Feeding mastitic milk to calves.J. Dairy science, 64: 719-720. 
- Klastrup, N.G. and Halliwell,R.W.(1977): Prevalence of bovine subclinical mastitis in Mallawi.Nordisk Veterinaermedicin 29,7/8:33.

- Koneman, E.W.;Allen, S.D.; Dowell,V.R.; Sommers, H. M.; Janda, W.M. and Winn, W.C. (1988): Color Atlas and text Book of Diagnostic Microbiology. $3^{\text {rd }}$ Ed., J.B. Lipincott co., Pheladelphia, U.S.A.

- Liebisch, G.; Dorn, H. and Liebisch, A. (1994):Control of flies and summer mastitis in grazing cattle by use of Cyfluthrin-Societa Italiana di Buliatria (1) 765-768.

- Lopes, C. A. Dem; Morena, G.; Gonschalk,P.R.; Modolo, J.R.; Horacio, A.; Correa, A. and Payan, C. (1990): Characteristics of Staph. aureus from subclinical mastitis in Brazil .Br. Vet. J. 146 (6): 443-448.

- Misra, D.S. (1976): Bacterial Buffalo mastitis. pantnagar. J. of Research., 1,1,67,Vet.Bull. 48,8 (1978).

- Morselt, M.L.; Lam, T.J. G.M.; Wuckhuse, L.A. Van; Franken, P.;Hartman, E.G. and Schukken, Y.H.(1995): Reliability of bacteriological examination of mixed (whole milk )milk samples for diagnosis of subclinical mastitis in cows. Tijdschrify Voor Diergenee-skunde 120, 426-430.

- Narendra, S.; Siarma, V.K.:Rajani ,H.B. and siniaa, Y.R. (1982): Incidence economy and test efficacy of subclinical mastitis in dairy animal. Indian Vet. J.59:693-696.

- Nawal, Gh. Khalil; Seham, M. Aly; Bastawrows, A.F. and Mikhail. (1996): Bacteriological studies on subclinical and 
clinical mastitis in cattle and buffaloes. Bani-Suef, Vet .Med. Res.,6,201-207.

- Roberson, J.R.; Fox, L.K.;Hancock, D.D.;Gay, J.M.and Basser, T. B. (1994): Etiology of Staphylococcus aureus isolated from various sites on dairy farms .J. Dairy science 77:3354-3364.

- Rottschedt,W.(1994): Reliability of testing the electrical conductivity of milk in subclinical mastitis, Prakifsche Terarz 75 :987-990.

- Schalm, O.W.; Carrol,E.J.and Jain, N.C.(1971): Bovine mastitis. $1^{\text {st }}$., Leand Febiger Philadelphia, U.S.A.

- Seddek, S.R.; Abd el-Kader, H.A. and Abd el-Hafeez M.M. (1999): Bacteriological studies of subclinical mastitis in Friesian cattle in Assiut Governorate. Assiut Vet. Med. J. Vol.42 No.83:77-88.

- Seddek, S.R.; Abd el-Kader, H.A. and Bastaurows, A.F. (2000): Incidence of Pseudomonas organisms in clinical, subclinical mastitis and raw milk of cattle in Assiut Governorate. Assiut. Vet. Med. J. Vol. 44:139-148.

- Sharma, S.D.; Ari, P. and Saxena, S.G. (1977): A survey of mycotic infection of the udder of clinical and subclinical cases of mastitis in cows and buffaloes. Indian Vet. J. 54,284.

- Smith, A.; Westgrath, D. R.; Jones, M. R.; Neave. F. K; Dood, F. H. and Brander, G.C. (1967): Methods of reducing the incidence of udder infection in dairy cows. Vet. Rec., 81:504-510.

- Tawfik, M.S.;Nashed, S.M.; Gads, F. F. M.; Samira ElGibbaly; Farid, A. F. and Nada, S. (1984): Preliminary studies 
on bacteria recovered from milk of apparaently healthy udders in diary cattles at El-Ahram area with special reference to antibiotic sensitivity. Assiut Vet. Med. J.12:91-96.

- Tsnoev, P.;Glbinoy, G.and Kamburov, G. (1976): Incidence of subclinical mastitis in the different udder quarters in cows. Veterinrian Sbirko. 7,30.Cited after Dairy Sci. Abst. 39.7 (1977).

- Verma, N.D. (1978): Comparative incidence and economic loss due to subclinical mastitis in the Herd of Zebu , Gross-bred and exotic breeds of milk animals. Indian Vet. J. 55.1-7.

- Weiss, W.P.; Hogan, J.S.; Smith, K. L. and Habtel, K.H.(1990): Relationships among selenium, Vit. E. and mammary gland health in commercial dairy herds. J. Dairy Science, 73:381-390.

- Wilesmith, W.; Francis, P. and Wilson, C.D. (1986): Incidence of mastitis of Brttish dairy herds. Vet Rec. 118:199204.

- Wilson, D.J.;sears, P.M.; Gonzalez, R.N.;Smith, B.S.;Schutle, H.F.; Benett, G.J.; Das, H.H. and Jonson, C.K.(1996): Efficacy of florfenical for treatment of clinical and subclinical bovine mastitis. American Journal of Vet. Research. 75:526528.

- Zecconi, A.; Piccinini, R.; Bronzo, V.; Luzzago, G. and Ruffo, G. (1994): Influence of some herd factors on development of teat canal and intrammary infections . International society for Animal Hygiene Cs 12-Cs15.

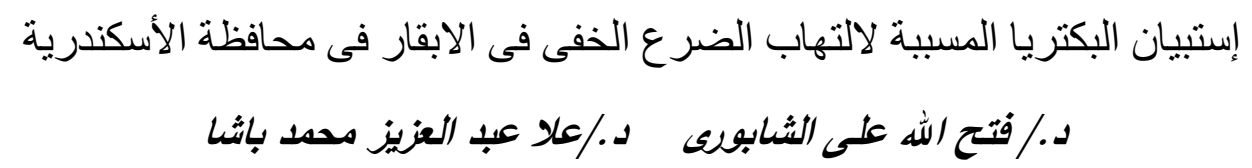

$\overline{\overline{\text { Kafrelsheikh Vet. Med. J. Vol. } 5 \text { No. } 2 \text { (2007) }}}$ 


\section{قسم البكتريولوجى / معهد بحوث صحة الحيوان - الإسكندرية}

شمل البحث عدد 80 عينة لبن من 80 ربع لبقرحلاب مصاب بالتهاب الضرع التحت إكلينيكى عن طريق الكثف السريع بإختبار كاليفورنيا وذلك من بين 600 عينة لبن من 600 ربع لعدد 150

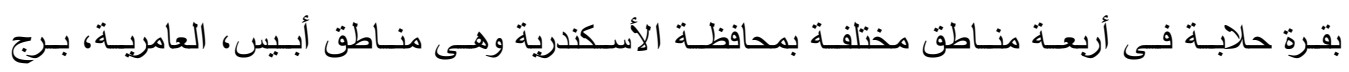

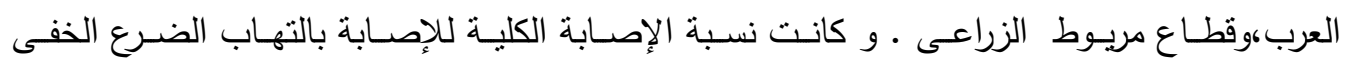
13.33 حيث كانت نسبة الإصـابة فى مـزارع مبطقـة أبيس 14.3\% و و العامريـة 13.9\% و و بـرج العرب 12.5\% و كانت الإصـابة فى مزارع قطاع مريوط الزراعى 10.0\% م و و لقد أوضحت النتائج

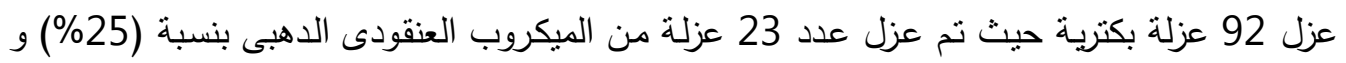

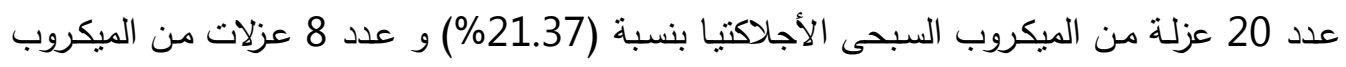
السبحى الديس أجلاكتيا بنسبة (8.69\%) و عدد 8 عزلات من الميكروب القولونى بنسبة (8.69\%)

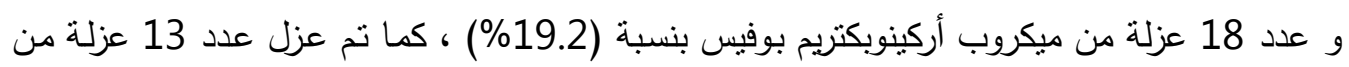
ميكـروب السـيدوموناس إيروجينوزا بنسبـة (14.13\%) و أخيـرا تـم عـزل عـد 2 عزلـــة مـن بكتريـا السيدوموناس فلورسنس بنسبة

(2.17\%) • و لقد تم إجـراء إختبـار الحساسية لهذه العترات البكتيريـة لعدد مـن المضـادات الحيوية المختلفة و كانت معظم العزلات البكتيرية

شديدة الحساسية لكل من الكلورامفنيكول و الجنتاميسين و السيفالوكسين و كانت قليلة الحساسية

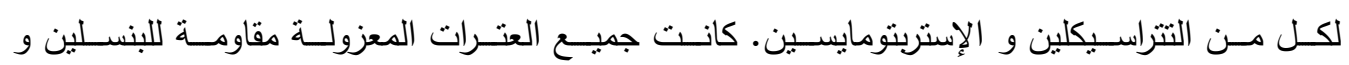
الأموكسيسيللين.

وقد تمت مناقثة الخطورة الصحية لهذه الميكروبات المرضية على الصحة العامة و كذلك طرق الحد من إنتشارها. 